\title{
PENERAPAN MODEL PEMBELAJARAN KOOPERATIF TIPE NUMBERED HEADS TOGETHER (NHT) BERBANTUAN WORD SQUARE UNTUK MENINGKATKAN PENGUASAAN HURUF HIRAGANA SISWA KELAS XI IBB 1 SMA NEGERI 1 GEROKGAK TAHUN AJARAN 2018/2019
}

\author{
N.P.C.Agustian ${ }^{1}$ D.M.S. Mardani ${ }^{2}$ G.S. Hermawan ${ }^{3}$ \\ 123 Jurusan Pendidikan Bahasa Jepang, Universitas Pendidikan Ganesha, Singaraja,Bali \\ e-mail: agustian.ni.putu@undiksha.ac.id \\ desak.mardani@undiksha.ac.id satya.hermawan@undiksha.ac.id
}

\begin{abstract}
Abstrak
Penelitian ini bertujuan untuk 1) mengetahui peningkatan penguasaan huruf hiragana siswa melalui penerapan model pembelajaran kooperatif tipe numbered heads together (NHT) berbantuan word square, dan 2) mendeskripsikan respons siswa dalam pembelajaran bahasa Jepang setelah diterapkannya model pembelajaran kooperatif tipe numbered heads together (NHT) berbantuan word square. Subjek penelitian ini adalah siswa kelas XI IBB 1 SMA Negeri 1 Gerokgak tahun ajaran 2018/2019 yang terdiri dari 36 orang siswa. Pengumpulan data penelitian ini dilakukan dengan metode observasi, tes, dan kuesioner. Data dianalisis secara deskriptif kualitatif dan deskriptif kuantitatif. Hasil penelitian ini menunjukkan adanya peningkatan pada penguasaan huruf hiragana siswa. Pada hasil pre-test persentase ketuntasan siswa adalah 16,66 \%. Pada siklus I, persentase ketuntasan siswa adalah $72,22 \%$. Sedangkan pada siklus II, persentase ketuntasan siswa meningkat menjadi $100 \%$. Respons siswa terhadap penerapan model pembelajaran kooperatif tipe numbered heads together (NHT) berbantuan word square tergolong positif. Pada siklus I, rata-rata respons siswa adalah 42,1. Pada siklus II rata-rata respons siswa adalah 43,0. Berdasarkan hasil penelitian tersebut disimpulkan bahwa penerapan model pembelajaran kooperatif tipe numbered heads together (NHT) berbantuan word square dapat meningkatkan penguasaan huruf hiragana.

Kata kunci : Pembelajaran kooperatif tipe NHT, word square, huruf hiragana
\end{abstract}

\section{要旨}

本研究の目的は、1) 平仮名を身に付けるためのWord Squareを使用したNumbered Heads Together (NHT) 協同学習方法の向上、2) Word Squareを使用したNumbered Heads Together (NHT) 協同学習 方法に対する学習者の反応を明らかにすることである。調査協力者は2018/2019年度第一グロガック 国立高等学校言語クラスの11年生の36名である。観察、テスト、及びアンケートによる収集したデー 夕を定量的および定性的な記述法により分析した。その結果、学習者が平仮名を書く能力は向上可能 性があり、身につけることが出来たことが分かった。事前テストの結果では学習者の合格率が

$16.66 \%$ 、一回目のサイクルで学習者の合格率が $72.22 \%$ 、二回目のサイクルで学習者の合格率が $100 \%$ であった。平仮名を身に付けるためのWord Squareを使用したNumbered Heads Together (NHT) 協同 学習方法に対して、学習者がポジティブな反応をした。一回目のサイクルでは学習者の反応の平均点 が42.1点であり、二回目のサイクルで学習者の反応の平均点が43.0点である。つまり、Word Square を使用したNumbered Heads Together (NHT) 協同学習方法により、平仮名を身につけることが出来 たと言える。

キーワード : Numbered Heads Together (NHT) 協同学習方法、Word Square、平仮名 


\section{Pendahuluan}

Bahasa Jepang merupakan salah satu bahasa yang saat ini banyak digemari dan dipelajari oleh masyarakat luas. Hal ini dikarenakan bahasa Jepang memiliki keunikan dan ciri khas tersendiri yang cukup menonjol. Salah satunya dapat dilihat dari jenis huruf Jepang yang terdiri atas tiga jenis huruf yaitu huruf hiragana, katakana dan juga kanji. Ketiga huruf tersebut memiliki fungsi yang berbeda dan tingkat kesulitan yang berbeda pula. Dalam mempelajari bahasa Jepang khususnya disekolah, hal utama yang harus dikuasai dengan baik oleh siswa adalah penguasaan huruf. Huruf pertama yang diperkenalkan pada pembelajaran adalah huruf hiragana, hal ini dikarenakan huruf hiragana adalah huruf dasar dan akan lebih banyak dipergunakan oleh siswa selama mempelajari materi bahasa Jepang di sekolah. Siswa dituntut untuk mampu menguasai huruf hiragana, baik itu membaca, menulis dan juga menggunakan huruf hiragana. Apabila siswa mampu menguasai huruf hiragana dengan baik, maka akan mempermudah proses pembelajaran didalam kelas.

Berdasarkan hasil observasi awal yang sudah dilakukan, pada kenyataannya banyak siswa yang belum mampu menguasai huruf hiragana dengan baik. Siswa masih kesulitan membedakan huruf-huruf hiragana yang memiliki kemiripan bentuk seperti huruf ま、も、は 、ほ、れ、ね、め、ぬ、ば、ば, sehingga hal tersebut menghambat siswa dalam membaca dan menulis huruf hiragana. Untuk mengatasi permasalahan tersebut, maka diperlukan adanya suatu perbaikan pada strategi atau model pembelajaran yang digunakan. Salah satu model pembelajaran yang dapat digunakan adalah model pembelajaran kooperatif tipe numbered heads together (NHT) berbantuan word square. Penggunaan model pembelajaran ini juga disesuaikan dengan kebutuhan serta karakteristik siswa yang cenderung kurang fokus mengikuti pembelajaran, siswa kurang aktif, dan juga malu untuk bertanya dengan guru.

Model pembelajaran kooperatif tipe numbered heads together (NHT) merupakan model pembelajaran yang menggunakan sistem kelompok kecil dengan orang-orang yang memiliki kemampuan akademik yang berbeda. Model pembelajaran ini dapat menjadikan siswa berpikir aktif, mampu bekerja sama dalam kelompok, bisa menyampaikan pendapat dan juga hasil diskusi. Sehingga siswa yang awalnya tidak aktif dalam proses pembelajaran akan dituntut menjadi aktif dan juga bisa bertanggung jawab atas hasil kerjanya. Hal ini juga sejalan dengan pernyataan Daryanto dan Rahardjo (2012:245) bahwa model pembelajaran kooperatif tipe numbered heads together (NHT) digunakan untuk melibatkan siswa dalam penguatan dan pemahaman untuk mengecek pemahaman siswa terhadap materi pelajaran. Selain itu, dalam belajar kelompok siswa bisa saling berbagi informasi dengan sesama teman. Menurut Kagan (dalam Mustami, 2018) model pembelajaran numbered heads together (NHT) menekankan pada kerja kelompok daripada individu kerja. Sedangkan penomoran pada masing-masing siswa dalam kelompok juga menjadikan siswa fokus mendengarkan apa yang diinstruksikan oleh oleh guru. Untuk memudahkan penerapan model pembelajaran kooperatif tipe numbered heads together (NHT) maka diperlukan suatu alat penunjang pembelajaran. Oleh karena itu lembar kerja word square akan diterapkan pada kelas XI IBB 1 untuk meningkatkan penguasaan huruf hiragana siswa.

Menurut Widarsana,dkk (2014:19) salah satu kelebihan dari model pembelajaran word square adalah melatih sikap teliti dan kritis pada siswa. Hal ini sejalan dengan karakteristik siswa yang masih kesulitan membedakan bentuk-bentuk huruf hiragana yang mirip. Lembar kerja word square hampir mirip dengan teka-teki silang, tapi bedanya pada lembar kerja word square sudah tersedia jawabannya namun disamarkan dengan kotak-kotak tambahan sebagai pengecoh. Lembar kerja word square ini dapat melatih ingatan siswa, sehingga siswa mampu membedakan huruf-huruf hiragana yang memiliki kemiripan bentuk.

Hal ini juga didukung oleh penelitian sebelumnya yang sudah pernah dilakukan oleh Cahyani,dkk (2015) tentang penerapan model pembelajaran kooperatif tipe numbered heads together (NHT) berbantuan word square. Penelitian tersebut menunjukkan adanya peningkatan hasil belajar siswa terkait kosakata bahasa Jepang. Penelitian sejenis lainnya yang sudah pernah dilakukan oleh Serinadi,dkk (2015) tentang penerapan model pembelajaran kooperatif tipe numbered heads together (NHT) menunjukkan peningkatan hasil belajar siswa yang signifikan terkait kemampuan menulis huruf hiragana siswa. 
Berdasarkan latar belakang tersebut, adapun rumusan masalah penelitian ini adalah 1) apakah penerapan model pembelajaran kooperatif tipe numbered heads together (NHT) berbantuan word square dapat meningkatkan penguasaan huruf hiragana siswa kelas XI IBB 1 SMA Negeri 1 Gerokgak Tahun Ajaran 2018/2019?, 2) bagaimana respons siswa kelas XI IBB 1 SMA Negeri 1 Gerokgak terhadap penerapan model pembelajaran kooperatif tipe numbered heads together (NHT) berbantuan word square?

\section{Metode}

Penelitian tindakan kelas ini dilaksanakan di SMA Negeri 1 Gerokgak pada semester II tahun ajaran $2018 / 2019$. Subjek yang digunakan pada penelitian ini adalah siswa kelas XI IBB 1 dengan jumlah siswa secara keseluruhan sebanyak 36 orang. Sedangkan objek pada penelitian ini adalah penguasaan huruf hiragana.

Penelitian ini direncanakan sebanyak 2 siklus, akan tetapi tidak menutup kemungkinan dilanjutkan ke siklus selanjutnya apabila belum memenuhi target penelitian. Pada setiap siklus akan dilakukan perencanaan penelitian, pelaksanaan tindakan, observasi/pengumpulan data, dan refleksi. Setiap akhir siklus, baik siklus I dan siklus II ditandai dengan adanya refleksi. Pada tahap refleksi akan dilakukan rencana perbaikan pada siklus selanjutnya agar kendala-kendala yang terjadi dapat teratasi dengan baik dan tidak terulang pada siklus selanjutnya. Berikut adalah bagan siklus penelitian yang digunakan pada penelitian ini.

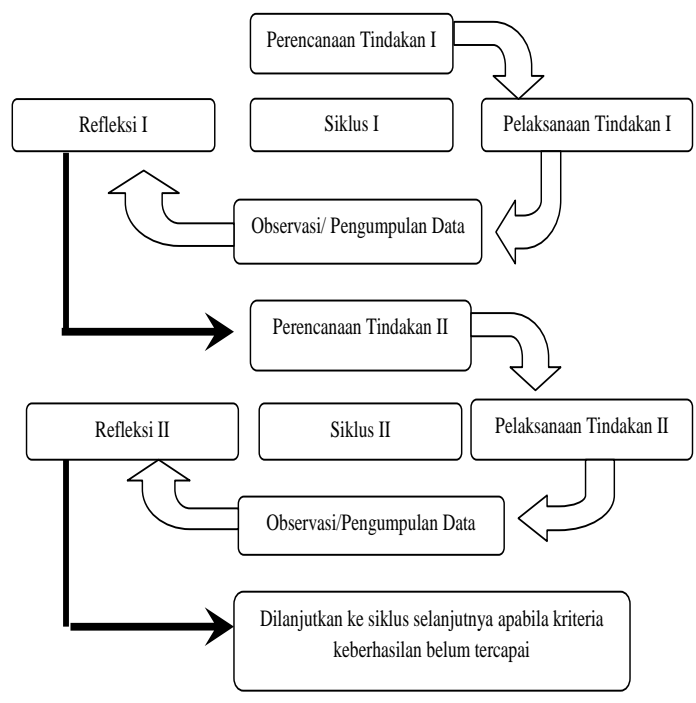

\section{Gambar 1}

Rancangan PTK

(Sumber: Arikunto, 2013:137)

Penelitian ini menggunakan empat metode pengumpulan data yaitu metode observasi, metode tes, metode kuesioner dan wawancara. Data hasil observasi dianalisis menggunakan pendekatan deskriptif kualitatif, sedangkan hasil tes serta kuesioner di analisis menggunakan pendekatan deskriptif kuantitatif.

Adapun rumus yang digunakan untuk analisis data hasil belajar adalah sebagai berikut.

Ketuntasan Individu :

Jumlah jawaban benar $\times 100$

Jumlah soal

Dalam menentukan persentase rata-rata hasil belajar siswa digunakan rumus sebagai berikut. 
Keterangan

$$
\mathrm{Me}=\frac{\sum \mathrm{Xi}}{n}
$$

$\mathrm{Me}=$ Mean (rata-rata nilai hasil belajar siswa)

$\Sigma \mathrm{Xi}=$ jumlah nilai tes seluruh siswa

$\mathrm{n} \quad=$ jumlah seluruh siswa

Rumus yang digunakan untuk menentukan persentase ketuntasan siswa dapat diketahui melalui rumus sebagai berikut.

Ketuntasan Klaksikal:

$\underline{\text { siswa yang memperoleh nilai } \geq 70 \times 100 \%}$

Seluruh siswa

Sedangkan untuk analisis data kuesioner menggunakan rumus sebagai berikut.

$$
P=\frac{f}{n} \times 100
$$

Keterangan

$$
\begin{aligned}
& \mathrm{P}: \text { Presentase Jawaban } \\
& \mathrm{f}: \text { Frekuensi Setiap Jawaban } \\
& \mathrm{n}: \text { Jumlah Responden }
\end{aligned}
$$

Berikut adalah penggolongan respons siswa.

Tabel 1

Penggolongan Respons Siswa

\begin{tabular}{|c|c|}
\hline Skor & Kriteria \\
\hline $\bar{X} \geq 45$ & Sangat Positif \\
\hline $35 \leq \bar{X}<45$ & Positif \\
\hline $25 \leq \bar{X}<35$ & Cukup Positif \\
\hline $15 \leq \bar{X}<25$ & Kurang Positif \\
\hline $\bar{X}<15$ & Sangat Tidak Positif \\
\hline
\end{tabular}

Kriteria keberhasilan penelitian ini apabila penguasaan huruf hiragana siswa dengan di terapkannya model pembelajaran kooperatif tipe numbered heads together (NHT) berbantuan word square mengalami peningkatan dalam proses pembelajaran dan hasil belajar. Penguasaan huruf hiragana siswa akan dianggap berhasil jika $75 \%$ dari keseluruhan siswa memperoleh nilai minimal KKM (Kriteria Ketuntasan Minimal) yaitu 70 maka tindakan penelitian dapat dihentikan.

\section{Hasil dan Pembahasan}

Tahap awal pada penelitian ini adalah melakukan observasi awal dan juga memberikan pre-test untuk mengetahui kondisi awal siswa sebelum diberikan perlakuan. Tujuan dari pemberian pre-test ini juga utuk mengetahui permasalahan yang dihadapi oleh siswa. Pre-test terkait penguasaan huruf hiragana dilaksanakan pada tanggal 27 oktober 2019 dengan jumlah soal sebanyak 20 butir. 10 soal mengubah dari huruf romaji kedalam huruf hiragana, dan 10 soal mengubah huruf hiragana kedalam huruf romaji. Dari hasil yang diperoleh, 30 orang mendapatkan nilai dibawah KKM dan hanya 6 orang siswa yang mendapatkan nilai diatas kriteria ketuntasan minimal (KKM). Nilai rata-rata yang diperoleh oleh siswa sebesar 52,77 \% dengan ketuntasan klaksikal sebesar 16,66 \%. Hasil pre-test disajikan dalam bentuk gambar sebagai berikut. 
Tabel 2 Hasil Pre-Test Siswa

\begin{tabular}{|c|c|c|}
\hline No & Nilai & Frekuensi \\
\hline 1 & $85-100$ & 1 \\
\hline 2 & $75-84$ & 2 \\
\hline 3 & $65-74$ & 5 \\
\hline 4 & $45-64$ & 19 \\
\hline 5 & $0-44$ & 9 \\
\hline \multicolumn{2}{|c|}{ Jumlah Skor } & 1900 \\
\hline \multicolumn{2}{|c|}{ Rata-Rata } & 52,77 \\
\hline \multicolumn{2}{|c|}{ Ketuntasan Klaksikal } & $16,66 \%$ \\
\hline
\end{tabular}

Berdasarkan hasil tersebut, diketahui bahwa penguasaan huruf hiragana siswa masih tergolong rendah, sehingga kemudian dilanjutkan pada siklus I dengan diterapkannya model pembelajaran tipe numbered heads together (NHT) berbantuan word square untuk meningkatkan penguasaan huruf hiragana. Masing-masing siklus dilakukan sebanyak 3 kali pertemuan dengan 2 kali pembelajaran dan 1 kali post-test. Pertemuan pertama pada siklus I dilaksanakan pada tanggal 28 maret 2019. Pada pertemuan pertama siswa masih terlihat kurang antusias dan juga bersemangat ketika mengikuti pembelajaran. Hal ini dibuktikan dengan banyaknya siswa yang masih terlihat main-main dan sibuk mengobrol dengan teman sebangkunya. Namun hal ini bisa diatasi dengan memberikan arahan dan juga memberikan pertanyaan untuk mengembalikan fokus siswa. Beberapa siswa sudah terlihat aktif dan fokus ketika mengikuti pembelajaran. Saat latihan menulis huruf hiragana pada genkouyoushi siswa masih terlihat kebingungan, namun setelah terbiasa siswa sudah mulai menikmati jalannya pembelajaran. Begitupun pada saat penerapan model pembelajaran kooperatif tipe numbered heads together (NHT) berbantuan word square, siswa kebingungan ketika diinstruksikan untuk menjawab lembar kerja word square yang diberikan. Untuk itu kembali dijelaskan secara detail tentang cara pengerjaan lembar kerja word square tersebut. Siswa juga diberikan kesempatan untuk bertanya apabila ada yang kurang dimengerti. Siswa juga bisa berdiskusi dengan teman kelompoknya dan saling berbagi informasi. Sehingga siswa pun menjadi lebih aktif. Saat menulis ke papan pun siswa masih terlihat takut salah dan juga ragu-ragu.

Pada pertemuan kedua siklus I yang dilaksanakan pada tanggal 30 maret 2019 , sudah mulai terlihat adanya peningkatan dalam proses pembelajaran. Siswa yang awalnya terlihat acuh saat mengikuti pembelajaran sudah mulai memperhatikan penjelasan guru. Pada saat penerapan model pembelajaran kooperatif tipe numbered heads together (NHT) berbantuan word square siswa sangat antusias menemukan jawaban-jawaban pada kotak. Keaktifan siswa pun sudah mengalami kemajuan, beberapa siswa mulai bertanya dan juga aktif menjawab apabila diberikan pertanyaan. Apabila ada yang tidak bisa menjawab maka dibantu oleh temannya yang lain.

Pada tanggal 6 april 2019, dilaksanakan post-test siklus I untuk mengukur kemampuan siswa terkait penguasaan huruf hiragana yang sudah dipelajari sebelumnya. Tes yang diberikan sebanyak 20 butir soal, 10 butir soal mengubah huruf romaji kedalam huruf hiragana dan 10 butir soal mengubah huruf hiragana kedalam huruf romaji. Adapun hasil post-test I yaitu sebanyak 26 orang siswa mendapatkan nilai diatas KKM. Sedangkan 10 orang siswa lainnya belum memenuhi kriteria ketuntasan maksimal (KKM). Nilai rata-rata yang diperoleh siswa sebesar 72,22 dengan ketuntasan klaksikal 72, $22 \%$. Hasil post-test I akan disajikan dalam bentuk gambar sebagai berikut. 


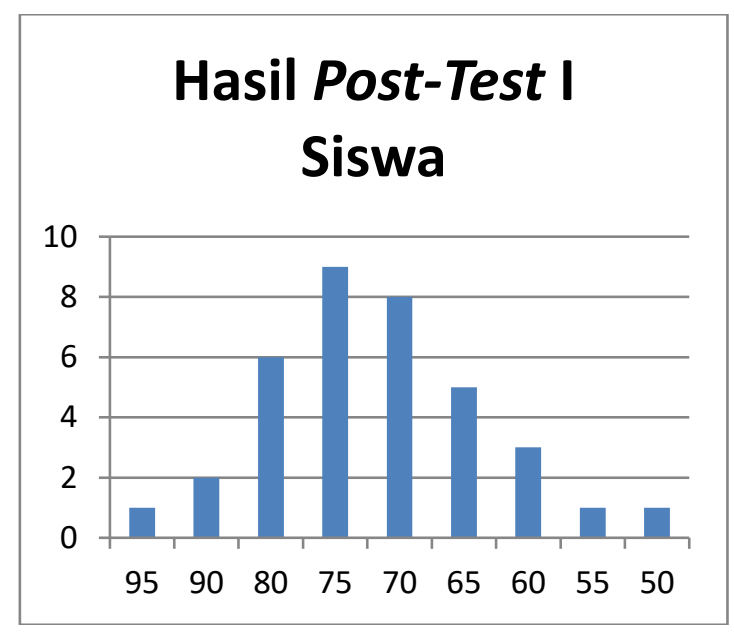

Gambar 2

Hasil Post-test I siswa

Untuk menjelaskan adanya peningkatan yang terjadi pada hasil belajar siswa, berikut perbandingan nilai hasil pre-test dan juga post-test I siswa disajikan dalam bentuk gambar sebagai berikut.

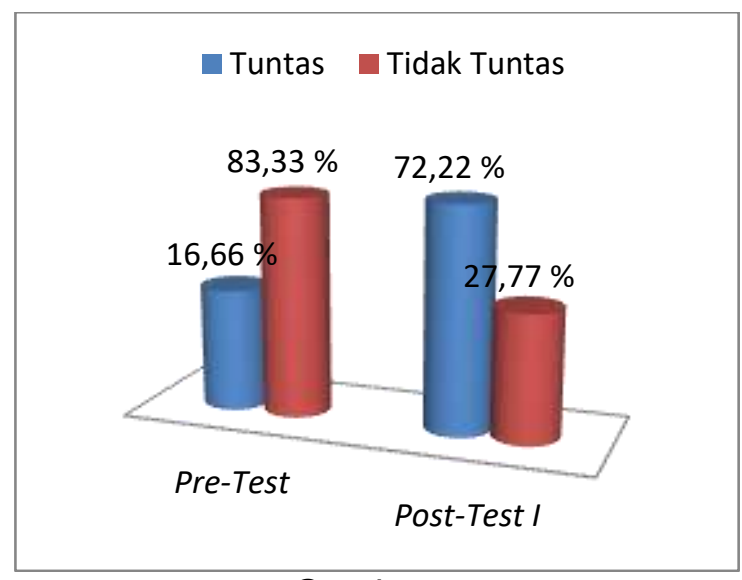

Gambar 3

Perbandingan hasil pre-test dan post-test I

Pada gambar 3 terlihat jelas adanya peningkatan hasil belajar siswa setelah di terapkannya model pembelajaran kooperatif tipe numbered heads together (NHT) berbantuan word square dalam meningkatkan penguasaan huruf hiragana. Akan tetapi perbaikan dipandang perlu dilakukan untuk meningkatkan penguasaan huruf hiragana siswa dan juga menguji kevalidasian data mengenai model pembelajaran kooperatif tipe numbered heads together (NHT) berbantuan word square pada siklus II dengan menerapkan metode yang sama.

Berdasarkan hasil kuesioner juga ditemukan hasil yang cukup beragam. Pada kuesioner tertutup diberikan 10 pernyataan mengenai respons siswa setelah mengikuti pembelajaran dengan diterapkannya model pembelajaran kooperatif tipe numbered heads together (NHT) berbantuan word square. Data-data yang sudah dianalisis dikumpulkan kemudian diakumulasi menjadi satu. Hasil kuesioner tertutup pada siklus I diperoleh skor sebanyak 1518 dengan rata-rata sebesar 42,1. Sehingga respons siswa tergolong kedalam respons positif.

Pada kuesioner terbuka, jawaban siswa pun cukup beragam. Sehingga jawaban siswa dikelompokkan berdasarkan kemiripan jawaban siswa agar memudahkan dalam mengklasifikasikan jawaban. Berdasarkan hasil jawaban siswa, model pembelajaran 
kooperatif tipe numbered heads together (NHT) berbantuan word square merupakan pembelajaran yang dapat meningkatkan motivasi, semangat dan juga ingatan siswa terkait huruf hiragana. Meskipun pada awal-awal pembelajaran siswa masih sedikit kebingungan dan kekurangan waktu.

Berdasarkan hasil observasi, tes dan kuesioner yang telah dilaksanakan ada beberapa kendala yang terjadi. Siswa masih beradaptasi dengan model pembelajaran yang digunakan, pengelolaan kelas yang masih kurang, siswa masih kekurangan waktu untuk menjawab, kurangnya rasa percaya diri siswa, dan siswa masih kebingungan membedakan beberapa huruf seperti huruf あ, お, ぬ, ね, め,は、ほ. Untuk itu perlu adanya perbaikan agar kendala tersebut tidak terulang pada siklus II. Pada siklus II akan dijelaskan kembali tentang penerapan model pembelajaran kooperatif tipe numbered heads together (NHT) berbantuan word square, saat membagi kelompok, siswa langsung diinstruksikan untuk duduk secara berkelompok di tempat yang sudah disediakan, memberikan wakt tambahan untuk siswa berdiskusi, memberikan motivasi atau pujian kepada siswa serta huruf-huruf yang menjadi kendala diulang kembali pada siklus II.

Pertemuan pertama pada siklus II dilaksanakan pada tanggal 27 april 2019. Pada saat pemberian materi huruf hiragana, siswa sudah mampu berlatih sendiri pada kertas genkouyoushi yang sudah dibagikan. Kemudian saat penerapan model pembelajaran kooperatif tipe numbered heads together (NHT) berbantuan word square dijelaskan kembali ada beberapa yang bertanya. Akan tetapi pada pelaksanaannya siswa sudah terlihat tertib, mampu berdiskusi dengan sesama teman kelompoknya da juga rasa percaya diri siswa sudah mulai terlihat. Hal ini terlihat dari keantusiasan siswa saat menjawab soal ke depan. Siswa yang awalnya masih ragu dan takut salah menulis kini sudah berani mencoba. Hal ini menunjukkan adanya suatu peningkatan kearah yang positif.

Pertemuan kedua pada siklus II dilaksanakan pada tanggal 02 mei 2019. Tidak jauh berbeda dengan pertemuan pertama pada siklus II. Keaktifan siswa masih sama pada saat pertemuan pertama siklus II. Siswa mampu merespons pertanyaan yang diberikan dengan cepat dan juga saat mengerjakan lembar kerja word square siswa sudah tidak menemukan hambatan lagi. Setelah pertemuan kemudian dilanjutkan dengan pemberian post-test II kepada siswa untuk mengukur kembali kemampuan siswa terkait penguasaan huruf hiragana.

Pemberian post-test II dilaksanakan pada tanggal 16 Mei 2019 dengan soal sebanyak 20 butir soal. 10 soal mengubah huruf romaji kedalam huruf hiragana dan 10 soal mengubah huruf hiragana kedalam huruf romaji. adapun hasil post-test II yaitu seluruh siswa sudah mampu mendapatkan nilai diatas KKM. Nilai tertinggi yang diperoleh oleh siswa adalah 95. Berikut adalah hasil post-test II siswa yang disajikan dalam bentuk gambar sebagai berikut.

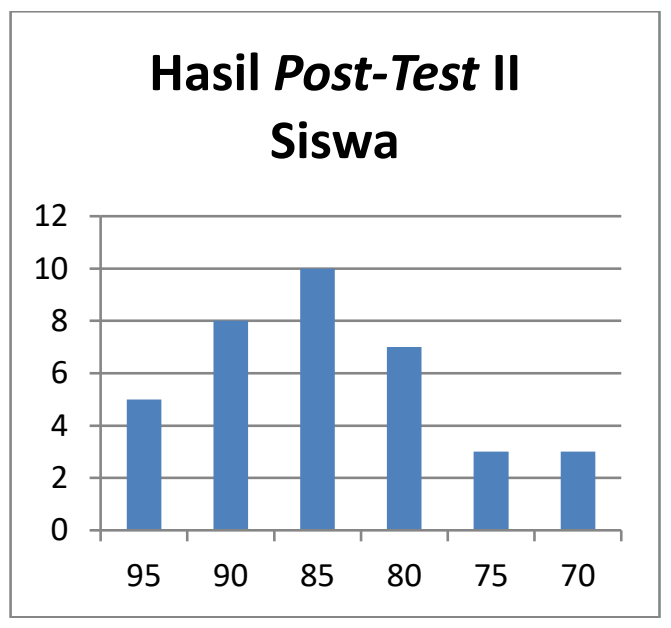

Gambar 4

Hasil post-test II siswa 
Berdasarkan gambar 4 tersebut dapat dipaparkan bahwa nilai rata-rata yang diperoleh siswa sebesar 84,44 dengan ketuntasan klaksikal yaitu $100 \%$. Hal tersebut menunjukkan adanya peningkatan hasil belajar yang cukup signifikan. Selain itu, berikut adalah hasil perbandingan pre-test, post-test I dan post-test II yang disajikan dalam bentuk gambar sebagai berikut.

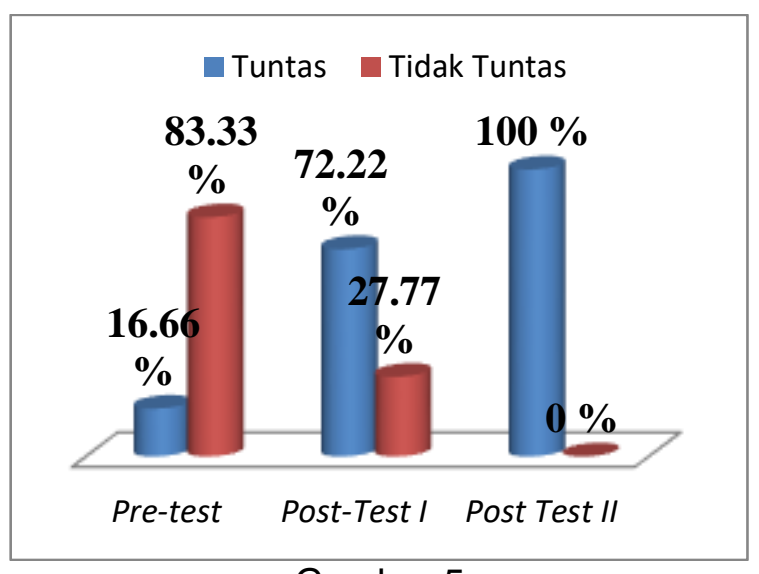

Gambar 5

Perbandingan hasil pre-test, post-test I dan post-test II

Berdasarkan gambar 5 , dapat dilihat suatu peningkatan yang terjadi pada hasil belajar siswa setelah diterapkannya model pembelajaran kooperatif tipe numbered heads together (NHT) berbantuan word square. Hasil tes ini juga didukung dengan adanya hasil kuesioner.

Berdasarkan hasil kuesioner yang diberikan kepada siswa kelas XI IBB 1, pada kuesioner tertutup dengan 10 pernyataan yang diberikan diperoleh akumulasi skor keseluruhan siswa sebanyak 1551 dengan rata-rata yaitu 43,0. Respons tersebut tergolong kedalam respons positif. Selain kuesioner tertutup, pada kuesioner terbuka juga menunjukkan respons yang positif.

Refleksi terhadap tindakan siklus II dilaksanakan berdasarkan hasil observasi, tes dan kuesioner. Pada siklus II proses pembelajaran sudah tergolong baik. Hal ini dibuktikan dengan adanya peningkatan proses belajar siswa dan juga adanya peningkatan hasil belajar. Dalam satu kelompok memiliki satu orang siswa yang menjadi koordinator untuk memandu anggota-anggotanya. Siswa tersebut mengarahkan anggotanya untuk fokus mengerjakan word square yang diberikan dan memecahkannya secara bersama-sama. Peningkatan lainnya terlihat dari hasil tes siswa yang menunjukkan ketuntasan klaksikal yang diperoleh siswa sebesar $100 \%$. Hasil kuesioner juga menunjukkan respons positif, hal ini dibuktikan dengan jumlah hasil rata-rata jawaban respons siswa sebanyak 43,0. Dari pemaparan tersebut dapat dikatakan bahwa pelaksanaan siklus II telah mencapai kriteria keberhasilan yaitu $75 \%$ sehingga penelitian dapat dihentikan.

Pembahasan dalam penelitian ini akan memaparkan dua temuan yaitu 1) apakah penerapan model pembelajaran kooperatif tipe numbered heads together (NHT) berbantuan word square dapat meningkatkan penguasaan huruf hiragana?. 2) bagaimana respons siswa terhadap penerapan model model pembelajaran kooperatif tipe numbered heads together (NHT) berbantuan word square?.

Berdasarkan pada temuan penelitian yang dilakukan di kelas XI IBB 1 dengan diterapkannya model pembelajaran kooperatif tipe numbered heads together (NHT) berbantuan word square untuk meningkatkan penguasaan huruf hiragana telah mengalami peningkatan. Peningkatan yang terjadi tidak hanya pada peningkatan hasil belajar siswa, akan tetapi meningkat pula pada proses belajar siswa di dalam kelas. Siswa yang kurang aktif dan tidak fokus ketika mengikuti pembelajaran sudah mulai menunjukkan adanya perubahan kearah yang positif. Siswa melakukan diskusi dan saling bertanya dengan teman sesama kelompok dalam menyelesaikan permasalahan yang diberikan. Hal ini juga melatih tanggung jawab siswa secara kelompok dan juga individu. Hal ini mengacu pada pernyataan Daryanto dan Rahardjo (2012) yaitu model pembelajaran ini dapat menjadikan siswa berpikir 
aktif, bekerja sama dalam kelompok, menegemukakan pendapat, dan berani menyampaikan hasil diskusi.

Pada observasi awal dan juga pre-test siswa masih kebingungan membedakan hurufhuruf hiragana yang memiliki kemiripan bentuk. Hal tersebut menunjukkan bahwa ingatan siswa terkait huruf hiragana siswa masih lemah, sehingga kemampuan membaca dan menulis pun menjadi terhambat. Oleh karena itu, selain diterapkannya model pembelajaran kooperatif tipe numbered heads together (NHT) ditunjang juga dengan lembar kerja word square sebagai alat untuk mengukur pemahaman siswa terhadap materi yang telah diajarkan. Hal ini sejalan dengan pernyataan Widiarsana (2014:19) kelebihan dari model pembelajaran word square yaitu mendorong pemahaman siswa terhadap materi dan juga melatih sikap teliti dan kritis siswa.

Untuk itu pelaksanaan tindakan pembelajaran dengan menggunakan model pembelajaran kooperatif tipe numbered heads together (NHT) berbantuan word square lebih banyak melibatkan keaktifan siswa dan juga melatih ketelitian siswa dalam mencari jawaban dari soal yang telah disediakan dalam kotak-kotak berbentuk huruf-huruf yang acak. Hal ini sejalan dengan pernyataan Kurniasih (2016:97) model pembelajaran ini memadukan kemampuan menjawab pertanyaan pada kotak-kotak jawaban mirip seperti teka-teki silang tetapi bedanya jawaban sudah ada namun disamarkan dengan menambahkan kotak-kotak tambahan dengan sembarang huruf atau angka sebagai pengecoh. Sehingga dalam kelompok siswa saling membantu dan berbagi pengetahuan untuk menemukan jawaban yang tepat. Siswa menjadi mampu mengingat bunyi dan bentuk dari masing-masing huruf yang memiliki kemiripan.

Selain itu berdasarkan hasil belajar juga mengalami peningkatan, hal ini terlihat dari hasil pre-test yang menunjukkan nilai rata-rata diperoleh siswa adalah 52,77 dengan ketuntasan klaksikal sebesar 16,66 \%. Pada post-test I nilai rata-rata yang diperoleh siswa yaitu $52,77 \%$ dengan ketuntasan klaksikal 72,22 \%. Sedangkan pada post-test II nilai ratarata yang diperoleh siswa yaitu 84,44 dengan ketuntasan klaksikal sebesar $100 \%$. Berdasarkan uraian tersebut dapat ditarik kesimpulan bahwa penerapan model pembelajaran kooperatif tipe numbered heads together (NHT) berbantuan word square mampu meningkatkan penguasaan huruf hiragana siswa kelas XI IBB 1 SMA Negeri 1 Gerokgak

Selain melakukan kegiatan pembelajaran dengan diterapkannya model pembelajaran kooperatif tipe numbered heads together (NHT) berbantuan word square, dan tes untuk mengukur kemampuan penguasaan huruf hiragana siswa, siswa juga diberikan kuesioner terkait respons siswa terhadap penerapan model pembelajaran kooperatif tipe numbered heads together (NHT) berbantuan word square untuk meningkatkan penguasaan huruf hiragana. Berdasarkan hasil kuesioner yang telah diberikan pada siklus I dan siklus II, sebagian besar siswa memberikan respons positif. Hal ini dibuktikan dengan adanya hasil rata-rata yang diperoleh pada siklus I dan siklus II. Pada siklus I rata-rata yang diperoleh sebesar 42,1 sedangkan pada siklus II diperoleh rata-rata yaitu 43,0. Respons tersebut tergolong respons positif.

Berdasarkan hasil penelitian, diperoleh suatu implikasi sebagai berikut 1) penerapan model pembelajaran kooperatif tipe numbered heads together (NHT) berbantuan word square menjadi solusi untuk permasalahan siswa yaitu penguasaan huruf hiragana. Siswa sudah menjadi lebih aktif, fokus dan juga teliti dalam mengikuti pembelajaran. Selain itu siswa juga sudah berani mengemukakan pendapat serta bertanya. Ingatan siswa terkait huruf hiragana pun sudah meningkat. Siswa sudah mampu membedakan bunyi dari hurufhuruf yang memiliki kemiripan bentuk. 2) respons siswa terhadap penerapan model pembelajaran kooperatif tipe numbered heads together (NHT) berbantuan word square adalah positif. Dalam mengikuti pembelajaran dengan diterapkannya model pembelajaran kooperatif tipe numbered heads together (NHT) berbantuan word square, siswa merasa dapat meningkatkan penguasaan huruf hiragana, baik itu mengingat, membaca, menulis, menggunakan dan membedakan huruf hiragana yang memiliki kemiripan bentuk. Siswa juga merasa lebih bersemangat dan aktif ketika belajar bahasa Jepang khususnya mempelajari huruf hiragana karena suasana belajar yang menyenangkan dan tidak membosankan. 


\section{Simpulan dan Saran}

Berdasarkan hasil analisis data tes, hasil belajar siswa mengalami peningkatan. Pada pelaksanaan pre-test persentase ketuntasan klaksikal yang diperoleh siswa sebesar 16,66 $\%$. Pada siklus I persentase ketuntasan klaksikal yang diperoleh siswa sebesar $72,22 \%$ dan pada siklus II kembali terjadi peningkatan persentase ketuntasan klaksikal sebesar $100 \%$. Hasil tersebut membuktikan bahwa pembelajaran kooperatif tipe numbered heads together (NHT) berbantuan word square mampu meningkatkan penguasaan huruf hiragana siswa kelas XI IBB 1 SMA Negeri 1 Gerokgak tahun ajaran 2018/2019.

Sedangkan berdasarkan hasil analisis kuesioner, respons siswa terhadap penerapan model pembelajaran kooperatif tipe numbered heads together (NHT) berbantuan word square tergolong positif. Pada hasil kuesioner terbuka juga menunjukkan respons yang positif.

Dari penelitian ini diharapkan dapat memberikan motivasi untuk guru agar menerapkan strategi, model, dan metode pembelajaran yang sesuai dengan karakteristik siswa. Sehingga mampu meningkatkan hasil belajar, rasa percaya diri siswa, sikap teliti dan kritis siswa. selain itu penerapan model pembelajaran kooperatif tipe numbered heads together (NHT) berbantuan word square cocok diterapkan dalam kelas heterogen. Hal ini terbukti dengan adanya peningkatan nilai masing-masing siswa.

Hasil penelitian ini juga diharapkan dapat dijadikan acuan untuk peneliti lain apabila hendak melakukan penelitian pada permasalahan yang berbeda atau mata pelajaran lainnya, namun tetap harus memperhatikan hambatan-hambatan yang terjadi. Sehingga pada penelitian selanjutnya tidak terjadi kembali hambatan yang serupa dan lebih disempurnakan. Serta hasil penelitian ini dapat digunakan untuk menambah ilmu pengetahuan.

\section{Daftar Pustaka}

Arikunto, Suharsimi. 2013. Prosedur Penelitian. Jakarta: PT Rieka Cipta.

Cahyani, Kadek Dwi, dkk. 2015. Penggunaan Model Pembelajaran Kooperatif Tipe Numbered Heads Together Berbantuan Lembar Kerja Word Square Untuk Meningkatkan Penguasaan Kosakata Siswa Kelas XI Bahasa 2 SMAN 1 Sawan Tahun Ajaran 2014/2015. Jurnal Pendidikan Bahasa Jepang Undiksha. Vol. 3, No.1, Edisi 2015. Singaraja: Undiksha. Tersedia pada https://ejournal.undiksha.ac.id/index.php/JJPBJ/article/view/5440. (diakses pada tanggal 14 november 2018).

Daryanto dan Mulyo Raharjo. 2012. Model Pembelajaran Inovatif. Yogyakarta: Gava Media. Kurniasih, Imas dan Berlin Sani. 2016. Ragam Pengembangan Model Pembelajaran Untuk Peningkatan Profesionalitas Guru. Jakarta: Kata Pena.

Mustami, Muh Khalifah. 2018. "The Effects of Numbered Heads Together-Assurance Relevance Interest Assessment Satisfaction on Students' Motivation". International Journal of Instruction. Vol.11, No.3, ISSN: 1694-609. Tersedia pada http://www.eiii.net/dosyalar/iii 20183 9.pdf. (diakses pada 15 november 2018).

Serinadi, Ni Luh Gede, dkk. 2015. Penerapan Model Pembelajaran Numbered Heads Together (NHT) Untuk Meningkatkan Kemampuan Menulis Huruf Hiragana Pada Siswa Kelas X A SMA Negeri 1 Kubutambahan Tahun Pelajaran 2014/2015. Jurnal Pendidikan Bahasa Jepang Undiksha. Vol. 3, No.1, Edisi 2015. Singaraja: Undiksha. Tersedia pada https://ejournal.undiksha.ac.id/index.php/JJPBJ/article/view/6277. (diakses tanggal 14 november 2018).

Widiarsana, Komang, dkk. 2014. Penggunaan Model Pembelajaran Kooperatif Tipe Student Teams Achivement Division (STAD) dengan Berbantuan Word square Untuk Meningkatkan Kemampuan Membuat Karangan Berbahasa Jepang Siswa Kelas XI IPB 1 SMA Negeri 3 Singaraja Tahun Ajaran 2013/2014. Jurnal Pendidikan Bahasa Jepang Undiksha. Vol.2 No.1, Edisi 2014. Singaraja: Undiksha. Tersedia pada https://ejournal.undiksha.ac.id/index.php/JJPBJ/article/view/4244. (diakses tanggal 14 november 2018 